\title{
ANALISIS KONTAMINASI TOTAL MIKROBA PADA BEBERAPA PRODUK IKAN SEGAR KABUPATEN KEPULAUAN SANGIHE
}

\author{
Jaka F. P. Palawe \\ Program Studi Teknologi Pengolahan Hasil Perikanan \\ Jurusan Perikanan dan Kebaharian Politeknik Negeri Nusa Utara \\ Kampus POLNUSTAR Tahuna, Telp. 0432 - 24745, Fax 0432-24744 \\ Korespondensi: *jakksfree@gmail.com
}

\begin{abstract}
Abstrak
Tujuan dari penelitian ini adalah untuk menganalisis tingkat kontaminasi total mikroba pada beberapa produk ikan segar/mentah di Kabupaten Kepulauan Sangihe. Hasil pengujian Total Bakteri empat jenis ikan di Pasar Towoe menunjukan bahwa ikan layang memiliki nilai tertinggi yaitu 106.833 koloni/gram dan terendah pada ikan selar 77.000 koloni/gram. Hasil pengujian Total Jamur menunjukan bahwa ikan layang memiliki nilai tertinggi yaitu 25,9 koloni/gram dan terendah pada ikan selar 19 koloni/gram. Nilai total bakteri dan total jamur empat jenis ikan di Pasar Towoe dalam kategori baik karena berada dibawah SNI ikan segar yaitu 5 × $10^{5}$ koloni/gram. Hasil analisa statistik varians menunjukan bahwa jenis ikan tidak berpengaruh terhadap nilai kontaminasi bakteri dan jamur, sedangkan hasil analisa korelasi dan regresi menunjukan bahwa nilai pertumbuhan total bakteri memiliki hubungan yang erat dengan pertumbuhan fungi atau jamur.
\end{abstract}

Kata kunci : Ikan segar, total bakteri, total jamur

\section{PENDAHULUAN}

\section{Latar Belakang}

Ikan merupakan salah satu sumber protein bagi manusia yang memiliki nilai gizi yang lebih baik dibandingkan jenisjenis hewan lainnya karena memiliki tingkat kandungan kolestrol yang lebih rendah dan mengandung asam-asam lemak omega 3 dan 6 yang sangat bermanfaat pada perkembangan jaringan otak manusia. Ikan juga merupakan sumber protein yang umumnya menjadi pilihan masyarakat karena memiliki harga yang relatif murah.

Kabupaten Kepulauan Sangihe memiliki potensi keunggulan daerah yaitu dari sektor sumber daya kelautan, dimana 93.8\% luas daerah adalah laut dan potensi 
sumber daya kelautan dan perikanan sebesar 34.000 ton/tahun dan yang baru dimanfaatkan baru berkisar $14.4 \%$ (Laporan Keterangan Pertangungjawaban Bupati Kabupaten Kepulauan Sangihe, 2012). Didalam rangka meningkatkan perekonomian rakyat Kabupaten Kepulauan Sangihe maka dilakukan pengembangan dari sektor kelautan perikanan sebagai tujuan utama, dengan salah satu sasaran yaitu terwujudnya kapasitas perikanan pasca tangkap, pengolahan dan industri. Produk ikan segar merupakan komoditas mayoritas hasil perikanan di Kabupaten Kepulauan Sangihe, Produk Ikan segar ini biasanya dijual di pasaran lokal dan biasanya dibeli dan di olah lagi menjadi bermacam-macam olahan ikan baik ikan olahan mentah maupun olahan menggunakan pemanasan atau pemasakan. Produk ikan segar hasil tangkapan nelayan tradisional memiliki banyak kelemahan di karenakan kurang di lakukannya proses pengontrolan mutu dari saat penangkapan, pendistribusian maupun pemasaran, sehingga mutu produk ikan segar yang dihasilkan sangat beragam. Mutu produk yang sangat beragam ini dapat mempersulit konsumen dalam hal pengolahan ikan selanjutnya. Salah satu komponen mutu yang sangat penting yaitu Total Mikroba.

Total mikroba merupakan parameter mutu yang menunjukan tinggi rendahnya tingkat kontaminasi suatu produk, mikroba pada umumnya merupakan sumber berbagai macam masalah kesehatan pada masyarakat misalnya diare oleh Escherichia coli, tipes oleh Salmonella Thyposa kolera oleh Vibrio cholera dan masih banyak lagi mikroba patogen yang menyebabkan berbagai masalah kesehatan.

Produk ikan segar merupakan produk yang memiliki resiko kontaminasi yang sangat tinggi, di karenakan ikan segar atau ikan mentah yang baru mati melakukan proses metabolisme yang sudah tidak terkontrol sehingga proses katabolisme/perombakan yang banyak terjadi, dimana hasil proses katabolisme dari ikan mentah merupakan substrat pertumbuhan untuk mikroba, sehingga produk ikan mentah lebih cepat rusak atau busuk dari pada produk ikan olahan. Selain itu $\mathrm{pH}$, aw, suhu, $\mathrm{RH}$, dan kontaminasi silang juga sangat berpengaruh pada proses kontaminasi dan pertumbuhan mikroba. Tujuan dari penelitian ini adalah untuk menganalisis tingkat kontaminasi total mikroba pada beberapa produk ikan segar/mentah di Kabupaten Kepulauan Sangihe.

\section{METODE PENELITIAN}

\section{Tempat dan Waktu Penelitian}

Penelitian ini akan dilaksanakan di Kabupaten Kepulauan Sangihe, untuk pengambilan sampel akan di ambil di pasar tradisional Towoe dan pengujian 
dilakukan di Laboratorium Perikanan dan Kebaharian Politeknik Negeri Nusa Utara.

\section{Alat dan Bahan}

Alat yang akan digunakan dalam penelitian ini adalah autoclave, laminari flow, cawan petri, tabung reaksi, dll. Bahan yang digunakan yaitu ikan cakalang, ikan layang, ikan tongkol dan ikan selar.

\section{Rancangan Penelitian}

Penelitian ini dilakukan menggunakan Rancangan Acak Kelompok (RAK), yang terdiri dari 4 perlakuan dan 3 ulangan. Perlakuan dalam penelitian ini yaitu :
A. Sampel Ikan Cakalang
B. Sampel Ikan Layang
C. Sampel Ikan Tongkol
D. Sampel Ikan Selar/Tude

Sedangkan Ulangan di lakukan selama 3 kali dalam jangka waktu 3 minggu, atau 1 kali perminggu.

\section{Parameter Pengujian}

Parameter dalam penelitian ini yaitu :

- pengujian Total Bakteri

- pengujian Total Jamur

\section{Prosedur Penelitian}

Pada penelitian ini dilakukan pengambilan sampel ikan mentah di pasar tradisional Towoe, dimana pasar ini menjual semua jenis hasil ikan tangkap dari seluruh Kabupaten Kepulauan Sangihe, untuk minggu pertama dilakukan pengambilan sampel ulangan pertama disertai dengan dokumentasi kemudian sampel dibawa ke Laboratorium Perikanan dan Kebaharian Politeknik Negeri Nusa Utara dengan cara di bungkus dengan tas plastik tanpa perlakuan apapun untuk dianalisis Total Bakteri,Total Jamur dan $\mathrm{pH}$, selanjutnya dilakukan pengambilan sampel ulangan kedua dan ketiga dengan prosedur yang sama pada minggu-minggu berikutnya. Hasil pengujian Total Bakteri dan Total Jamur ikan segar kemudian dianalisis menggunakan analisis statistic.

\section{Analisis Data}

Analisis data pada penelitian ini menggunakan analisis varians dari rancangan acak lengkap (RAK) kemudian jika berpengaruh nyata dilanjutkan dengan uji Beda Nyata Terkecil (BNT), Uji statistic lainnya yaitu uji korelasi dan regresi.

\section{HASIL DAN PEMBAHASAN}

\section{Total Bakteri}

Hasil pengujian Total Bakteri empat jenis ikan di Pasar Towoe Pada Gambar 1, menunjukan bahwa ikan layang memiliki nilai tertinggi yaitu 106.833 koloni/gram dan terendah pada ikan selar 77.000 koloni/gram. 


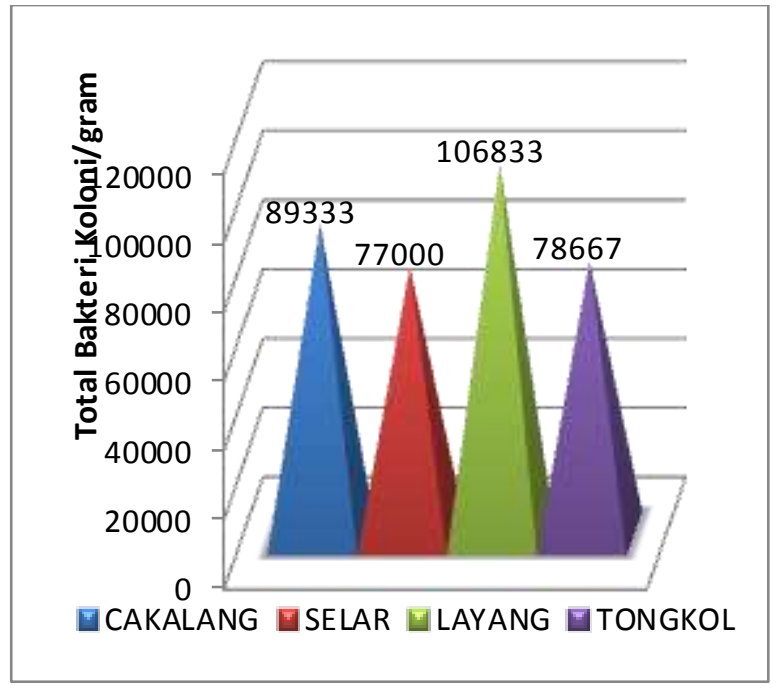

Gambar 1. Histogram Total Bakteri Empat Jenis Ikan Segar

Berdasarkan data histogram diatas, 4 jenis ikan segar yang diuji memenuhi SNI karena nilainya berada dibawah ketentuan nilai maksimum jumlah mikroba yang dipersyaratkan di Indonesia, Dengan nilai Maksimum Angka Lempeng Total Ikan Segar Berdasarkan SNI 01-27292006 adalah 5 x $10^{5}$ koloni/gram, Hal ini disebabkan karena proses pasca tangkap sampai ke konsumen dapat meminimalisir tingkat kontaminasi pada ikan misalnya dengan penggunaan es batu, waktu penangkapan di lakukan di malam hari sehingga suhu pasca tangkap rendah, lama transportasi dari kapal ke lokasi penjualan relatif singkat sehingga ikan yang di tawarkan masih dalam kondisi fresh atau belum sampai ke fase autolisis atau pembusukan. Menurut Djaafar (2007), kerusakan ikan dapat disebabkan oleh faktor internal seperti insang, isi perut, dan kulit yang merupakan sumber kontaminasi mikrobia. Koloni Bakteri Pada Cawan Media Nutrient Agar dapat dilihat pada Gambar 2.

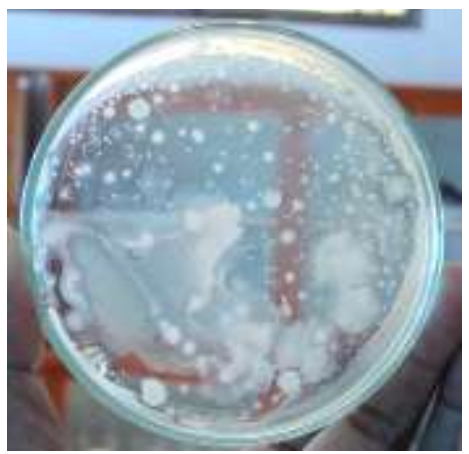

Gambar 2. Koloni Bakteri Pada Cawan Media Nutrient Agar

Hasil analisis varians total bakteri pada Tabel 1. Menunjukan bahwa jenis ikan tidak berpengaruh terhadap total pertumbuhan bakteri. Menurut Irianto dan Soesilo, 2007. ikan laut memiliki kandungan gizi yang tidak jauh berbeda yaitu kandungan protein 16-20\%, Lemak 1-15\%, karbohidrat 0- $4 \%$. Selain itu bagian tubuh dari ikan yang diambil dan dijadikan sebagai sampel pada penelitian ini adalah daging ikan. Insang, isi perut, dan kulit ikan tidak digunakan sebagai sampel. Menurut Jaya dan Ramadhan 2006, Distribusi bakteri pada ikan tidak merata, melainkan terpusat pada tiga tempat yakni lendir kulit, insang dan isi perut. 
Tabel 1. Analisis Varians Total Bakteri

\begin{tabular}{|c|c|c|c|c|c|c|}
\hline \multirow{2}{*}{ SK } & \multirow{2}{*}{ D.B } & J.K & \multirow{2}{*}{ K.T } & \multirow{2}{*}{$\begin{array}{c}\text { Fhi } \\
\mathrm{t}\end{array}$} & & \multicolumn{2}{|c|}{$\mathrm{F}$ tabel } \\
\cline { 5 - 7 } & & & & $\begin{array}{c}0.0 \\
5\end{array}$ & $\begin{array}{c}0.0 \\
1\end{array}$ \\
\hline Kelompok & 2.00 & $\begin{array}{c}2,497,54 \\
1,666.67\end{array}$ & $\begin{array}{c}1,248, \\
770,8 \\
33.33\end{array}$ & & & \\
\hline Perlakuan & 3.00 & $\begin{array}{c}1,693,72 \\
9,166.67\end{array}$ & $\begin{array}{c}564,5 \\
76,38\end{array}$ & $\begin{array}{c}1.4 \\
3^{\mathrm{b}}\end{array}$ & $\begin{array}{c}4.7 \\
6\end{array}$ & $\begin{array}{c}9.7 \\
8\end{array}$ \\
\hline Galat & 6.00 & $\begin{array}{c}2,361,45 \\
8,333.33\end{array}$ & $\begin{array}{c}393,5 \\
76,38\end{array}$ & & & \\
\hline Total & 11.0 & 6,89 & & & \\
\hline
\end{tabular}

Ket $:{ }^{\mathrm{tb}}=$ Tidak Berpengaruh

\section{Total Jamur}

Hasil pengujian Total Jamur empat jenis ikan di Pasar Towoe Pada Gambar 3, menunjukan bahwa ikan layang memiliki nilai tertinggi yaitu 25,9 koloni/gram dan terendah pada ikan selar 19 koloni/gram.

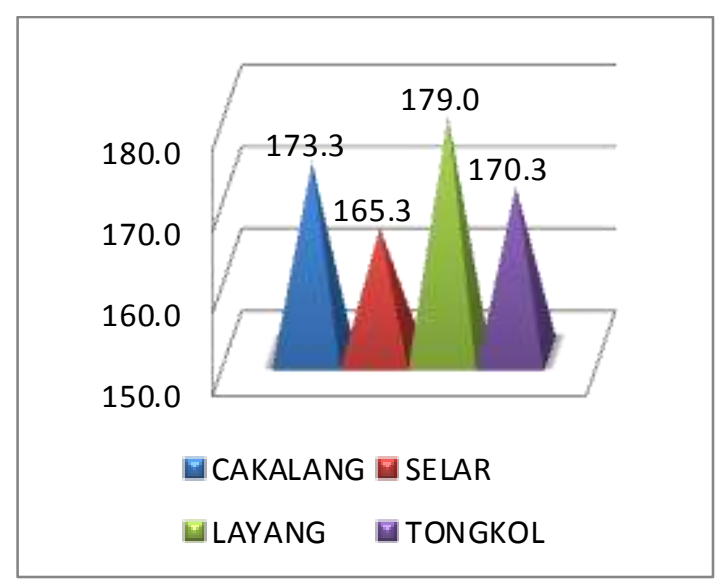

Gambar 3. Histogram Total Jamur Empat Jenis Ikan Segar

Berdasarkan data histogram diatas, 4 jenis ikan segar yang diuji memenuhi standar maksimum SNI 01-2729-2006 yaitu $5 \times 10^{5}$ koloni/gram. Tubuh ikan mempunyai kadar air yang tinggi (80\%) dan $\mathrm{pH}$ tubuh mendekati netral sehingga merupakan media yang baik untuk pertumbuhan bakteri pembusuk maupun jamur. Suhu optimum untuk pertumbuhan mikroorganisme yaitu $20-30^{\circ}$ C. Keadaan lingkungan pasar tradisional yang kurang higienis dapat memungkinkan mikroorganisme masuk kedalam ikan melalui udara. Wadah penyimpanan juga berpengaruh terhadap pertumbuhan jamur pada ikan, sehingga jika wadah sering terbuka maka mikroorganisme yang berada di udara berpotensi lebih besar untuk menkontaminasi ikan segar dibandingkan dengan wadah yang tertutup (Edyansyah, dkk 2003). Keadaan penyimpanan daging ikan segar yang cukup lama atau cara penyimpanan yang kurang baik akan memungkinkan jamur dapat tumbuh subur. Wadah penjualan yang kurang higienis serta lingkungan sekitar tempat menjual daging ikan segar juga bisa mempengaruhi pertumbuhan jamur pada daging ikan segar tersebut.

Tabel 2. Analisis Varians Total Jamur

\begin{tabular}{|c|c|c|c|c|c|c|}
\hline \multirow{2}{*}{ SK } & \multirow{2}{*}{ D.B } & J.K & \multirow{2}{*}{ K.T } & \multirow{2}{*}{ Fhit } & \multicolumn{2}{|c|}{ F tabel } \\
\cline { 4 - 7 } & & & & & 0.05 & 0.01 \\
\hline Kelompok & 2 & 1108.5 & 554.3 & & & \\
\hline Perlakuan & 3 & 294.0 & 98.0 & $0.265^{\text {tb }}$ & 4.75 & 9.78 \\
\hline Galat & 6 & 2221.5 & 370.3 & & & \\
\hline Total & 11 & 3624.0 & & & & \\
\hline
\end{tabular}

Hasil analisi varians total jamur pada Tabel 2. menunjukan bahwa jenis 
ikan tidak berpengaruh terhadap total pertumbuhan jamur. Menurut Kurniawati (2004) bahwa semakin lama bahan makanan disimpan maka akan tinggi pula tingkat kontaminasinya. Koloni Jamur Pada Cawan Media Potato Dekstrose Agar dapat dilihat pada Gambar 4.

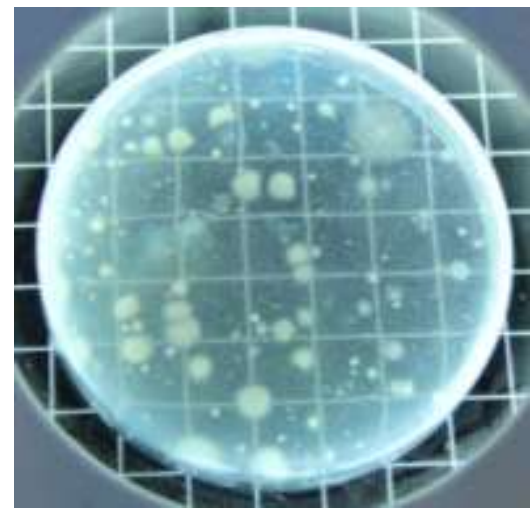

Gambar 4. Koloni Jamur Pada Cawan Media Potato Dekstrose Agar

\section{Korelasi dan Regresi Nilai Total}

\section{Bakteri dan Total Jamur}

Hasil iji korelasi pada Tabel 3 . Menunjukan Nilai total bakteri memiliki korelasi positif yang kuat dengan nilai total jamur yaitu dengan nilai 0,83 hal ini sejalan dengan penelitian Siburian dkk, 2012, Bahwa pertumbuhan Fungi (jamur) meningkat sering dengan pertumbuhan Bakteri pada Ikan Bandeng. Hasil uji regresi linier pada gambar 5 juga menunjukan bahwa adanya hubungan keterkaitan positif antara total bakteri dan total jamur dengan persamaan $\mathrm{Y}=0,04 \mathrm{x}+$ 1,367 .
Tabel 3. Korelasi Nilai Total Jamur dan

Bakteri

\begin{tabular}{|l|c|c|}
\hline \multicolumn{1}{|c|}{ Jenis ikan } & $\begin{array}{c}\text { Total } \\
\text { Bakteri }\end{array}$ & $\begin{array}{c}\text { Total } \\
\text { Jamur }\end{array}$ \\
\hline Cakalang & 89333 & 173.3 \\
\hline Selar & 77000 & 165.3 \\
\hline Layang & 106833 & 179 \\
\hline Tongkol & 78667 & 170 \\
\hline \multicolumn{2}{|c|}{ Korelasi } & $\mathbf{0 . 8 3}$ \\
\hline
\end{tabular}

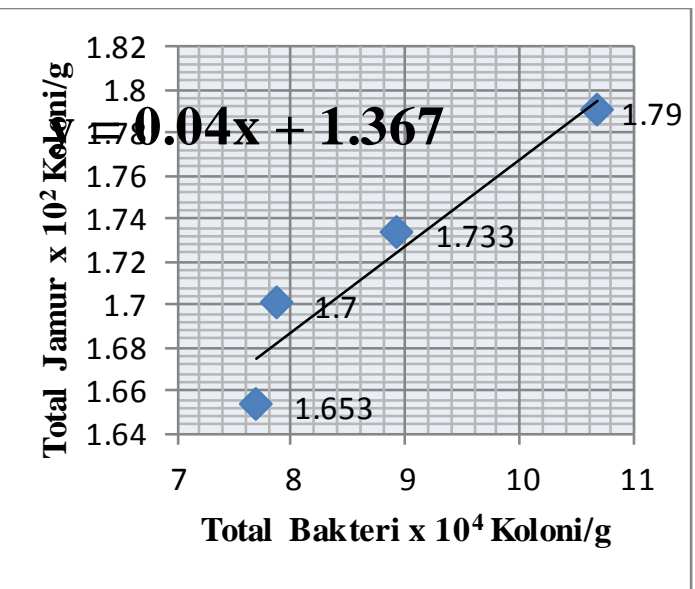

Gambar 5. Grafik Regresi Linier Total Bakteri Terhadap Total Jamur

\section{KESIMPULAN DAN SARAN}

\section{Kesimpulan}

Hasil pengujian Total Bakteri empat jenis ikan di Pasar Towoe menunjukan bahwa ikan layang memiliki nilai tertinggi yaitu 106.833 koloni/gram dan terendah pada ikan selar 77.000 koloni/gram. Hasil pengujian Total Jamur menunjukan bahwa ikan layang memiliki nilai tertinggi yaitu 25,9 koloni/gram dan terendah pada ikan selar 19 koloni/gram.

Nilai total bakteri dan total jamur empat jenis ikan di Pasar Towoe dalam 
kategori baik karena berada dibawah SNI ikan segar yaitu 5 x $10^{5}$ koloni/gram. Hasil analisa statistik varians menunjukan bahwa jenis ikan tidak berpengaruh terhadap nilai kontaminasi bakteri dan jamur, sedangkan hasil analisa korelasi dan regresi menunjukan bahwa nilai pertumbuhan total bakteri memiliki hubungan yang erat dengan pertumbuhan fungi atau jamur.

\section{Saran}

Saran dari hasil penelitian ini yaitu :

- Hasil dari penelitian ini dapat dijadikan refrensi dalam penelitian atau produksi ikan olahan baik mentah ataupun jenis ikan olahan lainnya di Kabupaten Kepulauan Sangihe.

- Penelitian dengan jenis ikan lain juga disarankan untuk memperolah data base yang lebih lengkap.

\section{DAFTAR PUSTAKA}

Anonimous,

2008.Repository.Ipb.Ac.Id/Tinjaua

n Pusraka.Pdf./ Komposisi Kimia

Ikan Layang.3 Januari 2014.

Azanza MPV, Ortega MP, Valdezco RG. 2001. Microbial Quality Of Rellenado Milkfish (Chanos Chanos, Forskall). Food Control $12: 365-371$.
Clucas IJ Dan Sutcliffe PJ. 1981. An Introduction To Fish Handling And Procesing. London : Tropical Products Institute.

Djaafar, T. F. 2007. Cemaran Mikroba Pada Produk Pertanian, Penyakit Yang Ditimbulkan, Dan Pencegahannya. Balai Pengkajian Teknologi Pertanianyogyakarta. Yogyakarta.

Ditjen Perikanan, 1998. Buku Pedoman Pengenalan Sumber Perikanan Laut Bagiani (Jenis-Jenis Ikan Ekonomi Penting).Direktorat Jenderal Perikanan Deptan, Jakarta.

Dwiari SR, Asadayanti DD, Nurhayati, Sofyaningsih M, Yudhanti SFAR, Yoga IBKW. 2008. Teknologi Pangan. Jakarta : Departemen Pendidikan Nasional.

Irianto, H. E Dan Indroyono Soesilo, 2010, Dukungan Teknologi Penyediaan Produk Perikanan. Badan Riset Kelautan Dan Perikanan Departemen Kelautan Dan Perikanan

Edyansyah. E, Herry Hermansyah, Nurhayati Ramli, 2013. Gambaran Keberadaan Jamur Kontaminan Pada Daging Ikan Giling Yang Dijual Di Pasar Tradisional Kota Palembang. Poltekkes Palembang 
FAO, 1974. Species Identification Sheets

For Fishery Purpose, Volume I

Food And Agriculture

Organization of The United

Nations, Rome.

Hidayati L. 2005. Pengaruh Suhu Dan

Lama Penyimpanan Dalam

Penyimpanan Freezer Lemari Es

Terhadap Kandungan Protein

Dan Jumlah Total Koloni

Bakteri Ikan Bandeng (Chanos

Chanos). [Tesis]. Universitas

Muhammadiyah Malang.

Jaya I dan DK Ramadhan. 2006. Aplikasi

Metode Akustik Untuk Uji

Kesegaran Ikan. Buletin

Teknologi Hasil Perikanan IX(2).

Kurniawati,B.B 2004. Identifikasi Jamur

Aspergillus Sp Pada Daging Ikan

Giling Yang Dijual Di Pasar Km

5 Palembang. Pendidikan Ahli

Madya Kesehatan Depkes :

Palembang.

Siswanto HP Dan Soedarto. 2008. Respon

Kualitas Bandeng (Chanos

Chanos) Asap Terhadap Lama

Pengeringan. Berkala Ilmiah

Perikanan 3 (1).

Siburian E.T.P, Pramesti Dewi dan Nana Kariada. 2012. Pengaruh Suhu Danwaktu Penyimpanan Terhadap Pertumbuhan Fungi Ikan Bandeng Bakteri Dan Unnes J Life Sci 1 (2) (2012) Unnes Journal Of Life Science Jurusan Biologi, FMIPA,
Universitas Negeri Semarang, Indonesia 